\title{
ARISTOCRACY AND POPULAR ENGAGEMENT IN REPUBLICAN ROMAN POLITICS
}

Jonathan Cruz Moreira ${ }^{1}$

\begin{abstract}
One of the recurrent themes in contemporary historiography on political and social organization of roman state resides on the participation or not of the population in decisions made in the different assemblies of roman citizens. Some of the discrepancies arise from the Roman citizens' sovereignty in these elections and the role of aristocracy in controlling these decisions, either through patronage system or by the assemblies' modus operandi themselves. The answer to these questions involves analyzing the place of aristocracy and plebs in this system, as well as the knowledge on the traditions system that ruled the res publica. This article aims at reflecting about the participation of the different social groups in Roman political process, by analyzing the political process and its traditions.
\end{abstract}

\section{Keywords}

Rome; plebs; politics; aristocracy.

\footnotetext{
${ }^{1}$ Postgraduate program in History - Master Degree. Universidade Federal de São Paulo - Guarulhos, SP, Brazil. email: jonathan.cruzmoreira@gmail.com
} 


\section{Resumo}

Um dos temas recorrentes na historiografia contemporânea acerca da organização política e social do estado romano, reside na participação ou não da população de modo efetivo nas decisões tomadas nas diferentes assembleias do povo romano. Algumas divergências surgem com relação à soberania do povo romano nestas votações e o papel da aristocracia no controle destas decisões, sendo por meio do sistema de clientela, ou pelos meios que o próprio funcionar das assembleias ofereciam. A resposta a estas questões passa pela analise tanto do lugar da aristocracia e da plebe nesse sistema, quanto pelo conhecimento do próprio sistema de tradições que regiam a res publica. O objeto deste artigo é refletir sobre a participação dos diferentes grupos sociais no processo político romano, por meio da análise do processo político e suas tradições.

\section{Palavras-chaves}

Roma ; plebe ; política ; aristocracia. 
The organization of Roman Republic and its structure, mainly concerning how its institutions operated, spans in contemporary historiography a reflection on the possibility of characterizing this same state structure as participative and democratic, or as an oligarchic due to limits and possibilities of an effective popular participation in the political process. This analysis can lead to the transposition of modern concepts to political realities that are far distinct in time and, shall they be applied to roman history take us to the observation of political structures always related to modern institutions, such as "Parliament" or legal tools like "constitution" or even the transposition of classic models, but more distant of roman reality like athens democracy.

By analyzing the modus operandi of the political apparatus of Roman Republic, one can come to a number of standstills in analyzing a very particular structure.

Unquestionably, they held (the Roman people) important constitutional power, at least in theory. But did it in fact matter what the voters in these assemblies thought about the issues on which they voted? Was the exercise of their power somehow pre-determined by patronage or political manipulation? Was power being exercised at all through political process of which we heard so much, or the apparent battle was just a meaningless side effect of a fixed system of authority vested in the ruling elite? (North, 1990:.277)

The debate that leads us to different approaches about the theme suggests a reflection on the nature of the Roman "constitution" itself or the set of rules, codes and traditions that ruled the political process, the assemblies where the magistrates were elected and their working system and, finally, the vote process and its practical consequences for the magistracies composition that would command the State in the following period. Rome, according to Brennan (2004) never owned a written constitution, under the modern semantics of the word, what means a founding legal act under which the other political areas regulate, having however a miscellaneous of regulations and political traditions that guide, shape and evaluate the relationships in public as well as in private scope:

Republican Rome had no written constitution. It did, however, have an array of remarkably tenacious continuing institutions (in the broadest sense of the word), some of which were, or at least seemed virtually primeval. (Brennan, 2004:31).

Even observing the institutions that formed the State and its legal structures from a distant perspective, all the comparison with modern systems of constitution and political organization can incur in the formulation of theories from anachronistically established basis.

The reconstruction of roman political system under the perspective of staatsrecht, established by Theodor Mommsen, ate the end of XIX century, from which the "Roman constitution" would be a system based on constitutional laws, what is, in an isolated and independent system, has been being replaced by an analysis that highlights the political and social systems, in which the institutions of Roman public life were inserted as unique and from which it is not possible to have a parallel analysis with modern politics. 
Even the conception of an "unwritten" constitution owns this comparative aspect. For Christian Meier (1966), the idea of a foundational written constitution is not necessarily opposed to an unwritten "constitution", although it can be contrasted with an "organic constitution". According to Hökenskamp (2010:15):

Contrasting with a "foundational" constitution, an "organic" constitution is capable of working with a minimum set of institutionalized structures due to the fact it is pragmatically developed and worked in political practices without much institutionalization or formalism.

Thereby, this organic constitution as Meier argues, since it is inherent to practical political life, is based on traditions and established precedents concerning the real situations of public life. In a society where public and private and is so confused, State and society end up mixing:

A particular, and peculiar, symbiosis of state and society, combined with a strong orientation toward the state - an exceptional focus upon "power", politics and war, rule and empire - with a high level of an asymmetrical kind of interpretation and interchange between society and state's institutions, powers and the procedures which subordinated to, indeed turned into, functions of a traditional society and its hierarchical order. (Meier, apud Holkeskamp, 2010:5).

The reasons why there hadn't been, throughout Roman Republic history, a systematic effort to create a definitive Roman political system, we can list the resistance from the Senate, aware of the fact that it could limit in some way their ample privileges and influences, apart from the fact that in the beginning of century II B.C. when the Latin legal literature was being developed, the political system, at least in its basis, was too ample to be encompassed as a whole. This conception, therefore, prevent us from describing accurately the system and its complexity. It can be described as a set or conglomerate of institutions and formal rules of political performance that were understood and applied in practice as a legal support and only occasionally improved, reformed or developed from laws (Holkeskamp, 2010).

This conglomerate of political practices and traditions cannot be understood however as a static system, but as a continuous political process which can only be analyzed taking into account the dynamics for the social groups' formation. This process was still based on an important framework of moral rules that guided public life. These "codes" of moral public behavior comprise a series of abstract concepts such as auctoritas, dignitas, gratia, e honos, and the most relevant of the all, mos maiorum.

The dispute for jobs and leading positions in Roman State depended deeply upon these personal or inherited values, socially accepted and legitimized, which reflected the importance of the individual as well as the family. The absence of a defined code on which the political relationships were guided made even more relevant this set of conditions and characteristics expected from a magistrate or a candidate to be developed by the State. The Greek Polybius (203 B.C. - 120 B.C.), who witnessed the Roman political practices, aiming at showing to his compatriots the reasons 
why Rome had become owner of most part of the known world, reminds us of the funeral traditions in Roman aristocracy.

Whenever one of their illustrious men dies, in the course of his funeral, the body with all of its paraphernalia is carried into the forum to the Rostra, as a raised platform there is called his son or, failing him, one of his relations mounts the Rostra and delivers a speech concerning the virtues of the deceased and the successful exploits performed by him in his lifetime. [...]These likenesses they display at public sacrifices adorned with much care. And when any illustrious member of the family dies, they carry these masks to the funeral, putting them on men as like the originals as possible in height and other personal peculiarities. And these substitutes assume clothes according to the rank of the person represented. If he was a consul or praetor, a toga with purple stripes; if a censor, whole purple; if he had also celebrated a triumph or performed any exploit of that kind, a toga embroidered with gold. [...] the speaker over the body about to be buried, after having finished the panegyric of this particular person, starts upon the others whose representatives are present, beginning with the most ancient, and recounts the successes and achievements of each. By this means the glorious memory of brave men is continually renewed; the fame of those who have performed any noble deed is never allowed to die. [...]But the chief benefit of the ceremony is that it inspires young men to shrink from no exertion for the general welfare, in the hope of obtaining the glory which awaits the brave (Polybius, apud, ROSENSTEIN, 2006, p.365).

Polybius's description of the funeral in Roman aristocracy shows the importance for the family of maintaining their symbolic power, based on military bravery and performance in public positions, as well as demonstrating it and making it public. The Forum, and mostly the Rostra, were places of free access where roles were performed, mainly communication, such as magistrates' and candidates' speeches and legal activities like defense and accusation in public judgments.

Furthermore, for the youngsters members of these families, it was essential that they were equal or better than their ancestors' memory, continuously renewed by civic traditions, after all: "Assuredly the matter stands thus: the glory of ancestors is, as it were, a light shining upon their posterity, suffering neither their virtues nor their faults to be hidden (Sallust, War of Jugurtha, 85.23). The military tradition, besides the political, also had special importance. When the last Etruscan king in Rome was expelled as set by the tradition in 519, the city was surrounded by other cities which were still under the rule of Etruscans, which threatened its fragile independence.

Its territory was just $800 \mathrm{~km}^{2}$. The walled city was constantly threatened by a possible attack and even the public assemblies could be interrupted by a simple waive of a flag, symbolizing imminent attack and the mobilization of the citizens who could engage only 2 legions, or about 8,000 men (Brunt, 1971:1).

According to Rosenstein (2006), the term virtus, although has carried a lot complexity throughout the centuries, has military origin and means bravery in the battle field. Consequently, the life of the young aristocrats who intended to move up in politics, conquering the same virtus of their ancestors, started with military service at the age of seventeen and from when they could candidate to public positions. In spite of the historiographical consensus on the bellicosity of 
Roman aristocracy due to the importance of bravery reputation in battles, this aspect was not sufficient for a fast moving up in the political career.

The performance in accusation and defense in tribunals (for those no payment was permitted) was also used for a fighting arena, where aristocrats competed among themselves. The victory in important cases did not bring only public acknowledgment, but it also narrowed the relationships mainly between defendants and defenders. For that, the public speaking skills was essential for political career climbing up. "Only Orators who were skillful to convince the people's assembly to agree with their points of view could expect success and higher positions". The defense in judgments was an important part of the amicitia system which linked individual aristocrats and Roman or not Roman families by bounds of wealth, strength and dignitas which, according to Syme (2002) meant position, prestige and honor, to be firmly defended against political attacks. These bounds took place in patronage and political support, what was sanctified by marriages and even adoptions. "Amicitia was a political weapon, not a feeling based on harmony. Individuals draw the attention and fill in history, but the most revolutionary changes in Roman politics were performed either by families or by some men". (Syme, 2002:.12).

In century I, patronage (clientela) had substantially changed its original meaning of loyalty between plebs and a specific patrician house, from which it was expected mutual loyalty. The former patronage system was said to be inherited, according to the tradition, from Romulo, who divided the plebs under the protection of the patricians: "He placed the plebeians under the patrician's protection, permitting that each plebeian chose any patron they liked." Dionísio, 2.9.2). Dionysius also observes that, unlike the patronage system that existed in Athens, the Roman patronage of the first centuries did not allow corporal punishment and that was "a friendly connection, befitting fellow citizens" (Dionísio, 2.9.3). In the late Republican period, clientela among the prominent families and the plebs consisted of the food aid from the aristocracy in exchange for political support. Therefore, the repeated attempts to implement the practice of distributing free food subsidized by the State, from politicians without the same power of economic persuasion, in order to loosen these ties between clients and patrons and even more that is why the resistance of the aristocracy to these laws. Every morning the Roman aristocracy hosted their customers, friends and allies to the salutatio, a morning greeting in which they asked for favors and advice. Gelzer states that "The number of voters who would appear for him (applicant) can be calculated by the number of those who were waiting for them in the morning, escorted daily forming his constant entourage" $(1969$, p.38). As they went to the forum, their customers and friends followed in the procession, showing publicly their fides, fidelity to their allies and their auctoritas, authority exercised in public life and among its allies and opponents (Mouritsen, 2007).

The symbolic demonstration of the power in terms of symbolic accumulated capital during several generations, revived during the performance of magistracies by candidates whose families long ago had been losing prestige distanced from the highest circles of politics, or played by homines novus, candidates whose lineage not included high magistracies, was continued and was expressed in these rituals of public life, in which the political prestige was made visible to all. Regarding the 
latter ones, in particular the lack of symbolic heritage imposed difficulties to obtain important positions, and the vast majority of "new men" just came to median positions. Quintus Cicero warned his brother Marcus Tullius about the difficulties to be faced in the path of the consulate of $63 \mathrm{BC}$, since it was "new man", despite the skill in oratory:

Consider what city this is, what your objective is and who you are. Every day when you go down to the forum, this should be on your mind: "I am a new man; the consulate is my goal; this is Rome. Its "newness" in politics and the fact that no one in your family ever exerted senior magistrates in Rome is a weakness to be overcome by his fame as an Orator (Cicero, comentariolum petitiones, I. 10).

Another "new man", Gaius Marius, had to face aristocracy despise to be accepted even among the candidates for the consulate. His support request from another aristocrat, Metellus, was only successful because it had been accompanied by a "flood of letters from merchants and African soldiers endorsing the candidacy" (Konrad, 2006:173). They were in general members of municipal aristocracies emigrated to Rome, although some researchers like Mathias Gelzer, argue that the Roman aristocratic families eclipsed at the political game over time, were also welcomed as "new man" (Gelzer, 1969:36).

This range of symbolic concepts, grown in and disseminated by the Roman political class, was gathered in a broader coverage term: mos maiorum. The scope of the term mos maiorum makes it difficult to restrict the term to a unique concept without incurring in the term limitation. It can be understood as a set of moral and political traditions that were behind all the reviews of conduct of magistrates, from the beginning of the career to the end of it, and was based on historical precedent supported in ancestral manners:

This mental inventory of principles, traditional principles and rules of proper conduct, tested policies in time, regulations, and well-established practices not only prescribing social behavior of private life, but also regulated every "criminal" and "public" right, the official religion and the military system, as the ways and means of internal or external political conduct. Last but not least, mos maiorum also includes what may be called "constitutional conventions". (Holkenskamp, 2010:12).

Furthermore, the complex responsibility of the Senate, its regulations and rights were supported especially in habits and not on established laws and regulations, as well the general rules for the administration of provinces. Conflicting responsibilities between individual organs of the Roman state were also regulated by previous analysis and tradition. For this reason, for example, the strong Senate opposition to the project of Gaius Gracchus about the foundation of a colony in the place where the city of Carthage was, devastated at the end of the Third Punic War in 146 and its management of foreign affairs, such as Pergamum kingdom's treasure (Brunt, 1971). Foreign policy was the traditional prerogative of the Senate, therefore, a tribune of the plebs who trespass this prerogative, infringed habits and acted contrary to mos maiorum. 
The Romans placed a high value on tradition and thus took constitutional decisions, based on the claim of ancient precedents. "They called to the conception of the mos maiorus (ancestral customs) as a reliable guide to legitimacy, what implies that continuity was always desirable" (North, 2006:257).

The structure of the roman state, therefore, was based on an "organic constitution", largely a process in which the state was based on laws and regulations, but above all cultural elements that dictated the rules of social, personal and political conduct, from the rise and inauguration, even life after the magistracies and military commands. The values of the Roman aristocracy, virtus, auctoritas, dignitas, fides, etc. were ostensibly defended and above all demonstrated. Being among the greatest men of the Republic or relate to them was crucial in the increasingly disputed Republic politics in his later years. In the field of Roman politics, the magistracy represented important trophies to be acquired, even among the lower magistracies. Competitiveness urges when what was in dispute were the highest magistrates, like the praetors, censors and consuls, who brought honor and nobility to the family for generations, confirming or renewing their authority.

On the opposite side of the political structure of the Roman republic, which comprised the majority of voters, it was the plebeian population (plebs, mob) and formed an increasingly large layer of Roman society. It was formed by immigrants from various regions of Italy, and formed the mass of peasants, often impoverished facing competition from Latin land aristocracy, artisans and merchants who formed a profoundly heterogeneous urban mass sub represented by the patrician policy. Despite the poverty of much of the mob, a core for economic rise, linked mainly to trade, manufacturing and other crafts, came off the patrician dependence and, knowing its importance for the military defense of the city during the fourth century BC, initiate to claim, with support from impoverished rabble of Rome, greater political participation:

The revolt of the plebs against the patrician nobility since the beginning of the republic can only be explained by having at least a solid core of commoners partly free of economic, social, political and even moral obligations that weighed on dependents of a gens in relation to their patricians heads and, therefore, from falling mainly on the masses of the peasant population. (Alfoldy, 1989:26).

The intentions of greater political participation by emerging layers of the plebs and the hungry masses seeking in resistance opportunity of access land, for example, gave way to riots which intended to give more space to common people in city administration.

It was the first secession of the plebeians. Separating implied fewer men in defense of the city, at a time when the weak position in Lazio did not allow the reduction of the effective without risk the defense of the city. With the pressure for secession, the patricians had to give in gradually as Rome needed all his military force available, the plebs raising more possible positions of access in the Roman policy. The first positions reserved for the mob, beyond the first laws made in its benefits 
coincided with periods of military conflict in the region, and therefore the formation of the Roman magistracy is:

Characterized by the interaction of internal and external issues, such as tension and struggle for equal civil and political rights; the socio-economic weakness witnessed by the increase in debt bondage and the need to obtain land; threats and wars with the Latin and Etruscan cities. (Funari, 2009:91).

The table below demonstrates how the context of local wars favored the inclusion of part of the plebs in the political process, and was relevant to the process of formation and consolidation of Roman magistracy, of the highest to the lowest of the cursus honorum.

In the following table we can track the relationship between the achievements of plebeians during the fifth and fourth centuries and pressures on Rome exerted by the city-states of the Lazio region. We observed that the resistance of the plebeians in the form of military turn-out had significant effects when Rome was threatened. 


\section{Community integration and institutional training}

\begin{tabular}{|c|c|c|c|}
\hline YEAR & INTERNAL CHANGES & YEAR & EXTERNAL POLITICS \\
\hline 494 & $\begin{array}{l}\text { Secession Plebe (creation } \\
\text { of the tribunes of the } \\
\text { people and commoners } \\
\text { aldermen) }\end{array}$ & & Training an army against the Volsci \\
\hline 494 & Creation of the Questura & \multirow[t]{3}{*}{485 to 474} & \multirow[t]{2}{*}{ Early problems with the city shafts } \\
\hline 491 & Law XII boards & & \\
\hline 443 & \multicolumn{2}{|l|}{$\begin{array}{l}\text { Abolition of the consulate } \\
\text { and the creation of } \\
\text { military tribunes with } \\
\text { consular power. Creation } \\
\text { Censorship }\end{array}$} & \\
\hline \multirow[t]{5}{*}{367} & \multirow{5}{*}{$\begin{array}{l}\text { Licinia-Sextias laws - one } \\
\text { regulated the debt, } \\
\text { another possibly enabled } \\
\text { the commoners } \\
\text { possession of public land, } \\
\text { and a third abolished the } \\
\text { consular Tribune } \\
\text { reestablishing the } \\
\text { consulate under the } \\
\text { condition one of the } \\
\text { consuls should be a } \\
\text { commoner }\end{array}$} & 390 or 386 & Victory over Veios \\
\hline & & 386 & Gallic invasion \\
\hline & & 358 & Hostilities league Latin \\
\hline & & & $\begin{array}{l}\text { Submission of the Latin cities became allied } \\
\text { municipalities or cities of Rome }\end{array}$ \\
\hline & & 346 & \multirow[t]{2}{*}{$\begin{array}{l}\text { Submission of Volsci; domination of Campania and } \\
\text { treated with Carthage }\end{array}$} \\
\hline 366 & $\begin{array}{l}\text { Creation of the Pretura } \\
\text { and Edilato curul }\end{array}$ & & \\
\hline
\end{tabular}

SOURCE: FUNARI, 2009, P.92.

The result of the first successes of the plebs was the recognition of exclusively plebeian institutions like the plebeian assemblies (concilia plebis) and the Tribune of the plebs, a magistracy that belonged to a "state within the Roman state (Taylor, 1949:5)".

However, the possibility of political action of the plebs, already limited geographically by distance, was further restrained by the enlistment of new citizens in urban tribes in subsequent centuries and even more markedly after the "social war" in the first century BC. The assemblies that elected 
magistrates and approve laws, had the duty to reflect the sovereign will of the Roman populus. The experience of the operation of these institutions was far from the real representative of the population, at least of all their social groups.

The Roman people's assemblies form a body of institutions that intended, at least in political discourse represent the will of the Roman people, electing its magistrates who, from the power entrusted by the roman people exercised their auctoritas and imperium in his name. Besides the election of magistrates, it also formed the legislative body of the roman state, approving or not laws proposed by the representatives and debated in the Senate. Its history dates back to semi legendary expulsion of King Tarquin, The Proud, and the election of the first magistrate, the praetor (later consul). In those early years, the council was limited to centuriata comitia, which had already in the monarchic period. The plebeian institutions that were founded in the course of clashes between plebeians and patricians in the fifth and fourth centuries, came to be accepted gradually as well its deliberations. At the end of the second century and during the first century they had already been consolidated the comitia centuriata and the two tribal rallies, the concilia plebis and comitia tributa, besides the comitia curiata, which had already lost its importance and in the first century was only formality. These different ways of meeting by the Roman people, electing their representatives and approving its laws, keep specifics with each other both in the form of organization as the meeting place and in its prerogatives. 
a)

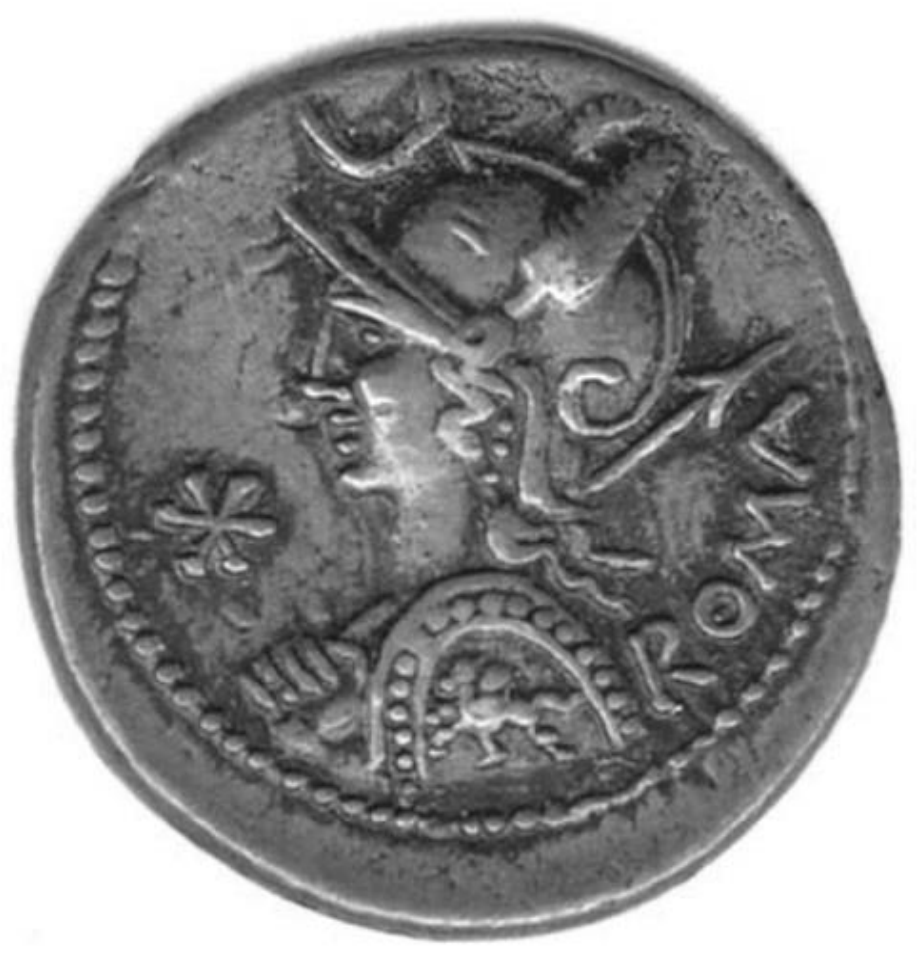

b)

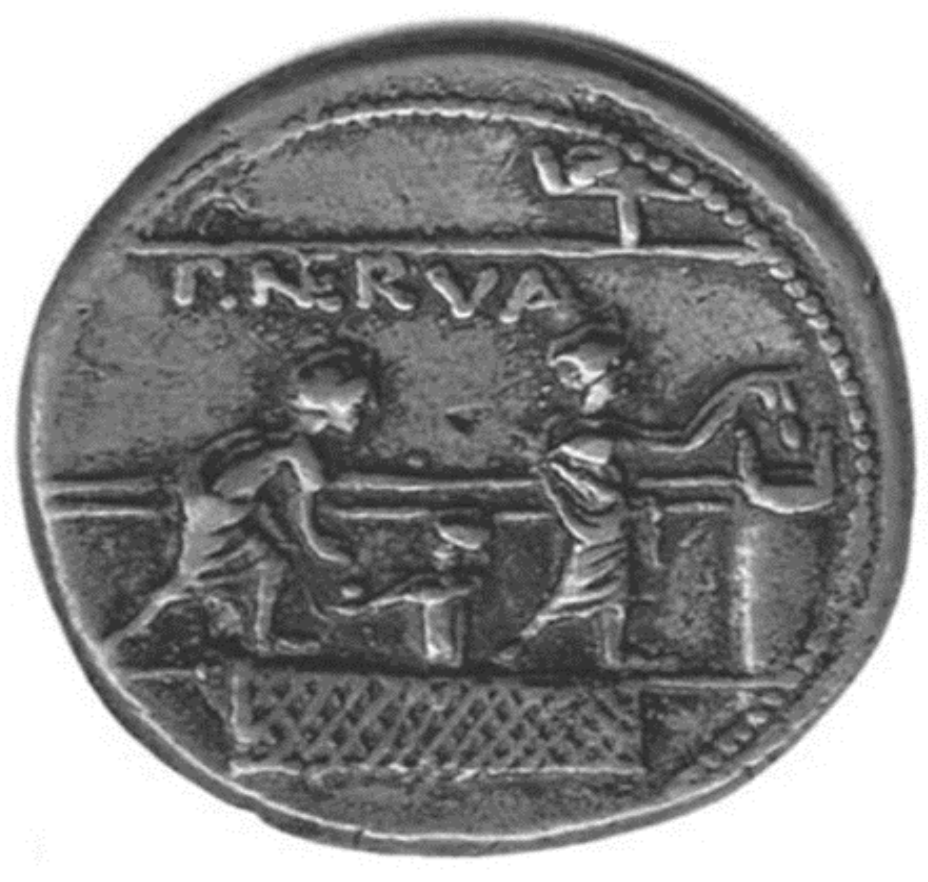

FIG.1 DENARIUS DE P. NERVA (POBJOY, 2006:73).

The figure above ( $a$ and $b$ ) is the image of a denarius dated from between 113 and 112 and coined by P. Nerva between 113 and 112 BC.: 
On the reverse, there is a figure on the right standing on a platform (pons), depositing the ballot in a ballot box, while on the left the next man to vote receives a ballot of a figure standing behind the platform. The two parallel lines and the line immediately on the coiner name of the currency, which seems to hold a board with a written letter (indicating the voting tribe?) Probably marks the area to vote. (Pobjoy, 2006:72)

According Mouritsen, the image represented on the coin is a scene in two moments of the same character, receiving the ballot and depositing the vote (Mouritsen 2007). Lily Ross Taylor also highlights the presence of custus, former rogator, in charge of delivering the ballots after the election changes established by Gaius Gracchus and Mario, a few years before. Taylor also points out that: It is remarkable that the man wears toga, not the traditional dress of the common people in Rome, what is clearly essential in the comitia (Taylor, 1966:39). The ballot, tabellae ceretae, consists of a wooden board covered with wax, where a letter was scratched. "The affirmative vote in a law was V to V (it), uti roga, "as requested ", and the negative was A, for antiquo," I keep things as they are. In judicial assemblies, votes were L and D. Libero and Damno" (Taylor 1966:35). Free and condemned respectively. When the vote was to elect a magistrate, the initial of the selected candidate was written off. This system was introduced from 139, when a tribune proposed the adoption of this form of ballot and secret ballot. Before that, the vote was oral. Each voter declared his vote to a rogator, who asked the votes and marked with a dot on boards already prepared with the names of candidates. Such system allows easy intimidation, fraud and falsification of such votes. On the reverse of the coin we see also the pons, the platform on which the voter, in possession of his board to vote, crossed to access the basket where the tablets with the votes were deposited, as shown in the coin, with the second individual represented. Behind this platform, giving the board to vote for the first figure is the custus, the supervisor in charge of procedure, as well as overseeing possible fraud or purchasing of votes (Taylor, 1966). Above the platform are the ropes that separate the offices where tribes or centuries were separated, waiting for their turn to vote.

The first of these meetings was the comitia cenuriata, basing their organization in the way the armies were organized. The centurias were organized from the old military contingent unit classes and that had a hierarchy according to the amount of equipment that could be provided in case of battle. The greater the number of individual properties, the more equipment could be used as according to the old model prior to the reforms of the late second century; the army was based on peasant soldiers who kept their equipment at their own expenses. There were 18 centuries of cavalry, which were grouped members of the patrician cavalry. These formed the supra classem, the class over the others (Alfoldy. 1989).

The prima classem, or first class, grouped 80 centurias. The richest commoners were in it. The other owners were clustered among the following three classes, each with 20 centurias. The fifth consisted of 30 centurias of the poor in general. There was also a lower than the others, where it is grouped the proletarii, which according to the census had no more than themselves or the offspring to serve the army of the city (Alfoldy, 1989). Each centuria represented a vote. With 98 votes available, adding 18 of supra classem and 80 of prima classem, which was decided between the 
richest voters it could hardly be reversed by other classes. The comitia cenuriata met outside the formal boundaries of the city, signaled by Pomerium the Mars field. In addition to the voting procedure tradition and religion permeated the Roman assemblies, such as comitia cenuriata. All voting ceremony was preceded by a prayer and a contio, a meeting in which were presented the key points of the legislation that would be voted on. It was always presided over by a Praetor in the case of judgment, or the magistrate who was to be replaced the following year by elected at the meeting. The magistrate ruled the entire procedure followed by an augure, a religious figure responsible for assessing the auspices and decide whether the procedure could follow or whether it should be stopped.

The comitia cenuriata, annually elected the chief magistrates, including the consul, the praetor and the censor and was the highest legislative body of the Republic until 218, when most of the laws began to be voted on in the tribal assemblies.

The 35 rural and urban tribes unlike the old tribal clans, which had been largely abandoned were purely local citizen groups depending on their place of residence or property. Every citizen was a member of one of these local tribes and be a member of a tribe was an essential part of citizenship. An abbreviation consisting of the first three letters of the name of his tribe was part of its official name. Cicero, for example, who came from Arpinium in Cornelia tribe, wrote his name as M. Tullius M.f.Cor.Cicero. The tribes would have been made by Serbian Tullius but not for vote, rather for census purposes, recruitment and tax collection. $\quad$ (Taylor 1966:59).

Were two forms of assembly with the organization based on geographical tribes. The comitia tributa and concilia plebis. Both distinguished by the fact that at first attended patricians and plebeians alike, while in the second only plebeians participated. According to Taylor 1966, the comitia tributa was chaired by consuls or praetors while the assembly of the plebs, was chaired by the tribune of the plebs and had different objectives. The assembly of the tribes, comitia tributa, approved laws sent from magistrates in addition to electing the lower magistrates that is those who were not elected in comitia cenuriata, as edis curul and quaestors.

The assembly of the plebs, elected the tribune of the plebs and plebeian aedile, and vote on the plebicita, legislations proposed by tribunes and had validity for the entire Roman people, playing an ambivalent role as at the same time defender of the rights of the people and freedom and as a senate arm "(Nippel 2003:20). Both gathered in the forum for trials. For elections, usually gathered in the Mars field at least in the late Republic. As the Roman voting system was based on the vote of the tribe, adding to the majority of individual votes, the 5 urban tribes in which were represented the majority of the less affluent population of Rome had no relevant political powers, being supplanted by the 30 rural tribes, fewer and where were the landowners. From 168, freed slaves were signed in a single tribe, among the urban tribes (Alfoldy, 1989).

The theoretical freedom, usually analyzed according to parallel-made classical Greek democracy, regarding the Roman assemblies, i.e., its legislative body prerogative and sovereign of voters of the Republic has been the basis of the argument of a stream of historians who recently attach to Republican system, a "democratic" feature. 
The main voice among the supporters of "democratic" approach of the Roman republic is the historian Fergus Millar. According Holkeskamp (2010:3):

For Millar, the populus Romanus itself was the sovereign power, inherent and truly), not merely in the abstract sense, formal, symbolic or ideological. The assemblies of the people comitia centuriata, comitia tributa and concilia plebis - always had the final say in the political process.

This line of analysis is therefore addressing the assemblies as an independent political body. The Intense competition for the senior positions in the administration of the Republic and the oratory tools and election campaigns would be evidence that Rome was, at his Republican period, a "direct democracy". "In this limited sense in their persuasion models (by presenting speeches, for those who could attend) and in the legislation of ways (by direct popular vote), the res system publishes Roman was rather democratic." (Millar 2002:225). The emphasis in this analysis is given especially in legislative prerogatives by the Roman assemblies: "The most fundamental of all rights of the people was the fact that the people, and only it could legislate" (Millar 2002:209).

Communication is also an important part of Millar analysis, which includes the speeches made at the rostra to the Roman public as part of a compliance culture necessary for success in public career. This scenario is countered by the argument of Morsten-Marx, according to which these speeches were no more than symbolic power since several speeches of different goals, most of them summoned to reading ordinances, were performed. In addition, none of those present could pronounce. (Morstein-Marx, 2004).

Other factors impeded the popular participation on the voting process to be held to the fullest. The first of them is related to Roman politics comprehensiveness, even in spatial terms. The dimensions of the places where the assemblies were held, being the forum, Jupiter Temple, or Mars field did not present conditions for a minimum significant part of the Roman plebe had access. Furthermore, the frequency of these assemblies and their duration were barriers for most part of the plebe whose time could not be wasted from work. The polls had to occur during the day. There were not polls during the night:

Based on estimates, 10,000 citizens would reunite for 15 hours, supposing that all tribes were called, and with additional time for the opening contio and the legislation reading. A more probable scenario would have involved about 3,000 citizens who would finish voting after 6 and half hours. Most of times the majority would have been reached before all the tribes had voted. (MOURITSEN 2007:23)

The Roman urban plebe, numerous and restricted in the 5 urban tribes, was rarely called for the polls, once the first tribes to vote were the rural tribes and once the majority was reached, the polls was concluded. Thus, at least in the period before the legislation of Tiberius and Gaius Gracchus, from 133 on, the groups that participated as listeners in the contio, as well as electors in the different assemblies, were people who were able to spend the necessary time in the assemblies. Furthermore, the difficulty of representation drove the plebe away the interest in involving in the political process. During all Republican period it was quite common that entire tribes were absent 
and in their places, members of other tribes were used so that the process could continue. In spite of rights equality, only a small part of populus could exercise theirs in fact. The social groups that really participated in the political process had, for that, similar ideals.

Henrick Mourtisen, in his work Plebs and politics in the late Roman republic, sees a rupture at the end of century II and beginning of century I. According to him, new political agents from Roman political elite go into play and change the political scenario.

Summarizing, before the populus moving up, the legislative rallies were not more than constitutional formality which served a small group, probably constituted of wealthy citizens who just rarely exercised the right of choosing. Most of them with Strong links with the political class. (MOURITSEN, 2007:79)

Following this analysis, the Roman politics has changed during the last decades of Republic in the aristocratic dispute aspect. The participation of plebe also changed, and according to John North it balanced important points in the different approaches of the republican electoral field. Consequently, the little possibility of the population's participation, one of the characteristics of archaic and median republic is not applied anymore when we analyze century I.

It is relatively easy to argument that the known conditions in the last years of Republic were not typical of the Republic as a whole: in this case, the collapse of conventions that marked the 60's and 50's BC can have resulted in the weakening of nobility authority. Thus, the same Roman electors started having initiative independence, something that had been never possible before. (NORTH, 1990:279)

From mid-century II, the attitude of searching political support changed. Through proposals which tried to meet Roman plebs' necessities, like for example land legislation, or subsided distribution of food, these new political streams started to move other social groups, at least in part, unrelated to politics.

This rupture in political paradigm did not occur due to the fact that traditional participants of comitia turned against the Senate. More likely, it was a consequence of the frequency of poorer members in assemblies they were not present before. It happened under the initiative of the magistrates who sought popular support to have some legislation against the Senate opposition or the wealthier classes approved. (MOURITSEN, 2007:79).

The growth of the Empire and its possibilities of gains, as well as the difficulties of administrating a vaster territory under a political model restricted to decisions taken in an only city made the competition in the political elite even fiercer. The necessity of defeating opponents in the political process being developed results in the need of new means, among them, seek for political support. Some intend to seek this support inside aristocracy, through the mobilization of older and more institutionalized spheres of politics. Other groups go after the mobilization of other agents which remained practically unrelated to politics until then due to difficulty in exercising their political rights as well as because of their lack of concern towards politics. This poorer class that, in century I, starts to be more frequently present at the decisions of res publica, always under the protection of 
political groups whose strategy concentrated on seeking help, was of vital importance for the consolidation of political dominance of names like Gaius Julius Caesar, Gnaeus Pompeius Magnus or Publius Clodius Pulcher. A broader distribution of citizenship rights, the division of public lands, the donation of grains donated by the government and games and public parties were political flags that attracted the population to aristocracy influence. This group, known as populares was an important tool for their conquering a great view in the political scenario:

During the time he performed as an aedile ornamented, apart from the comitium, also the forum, and the basilicas, as well as the Capitol, offering temporary porches that were aimed at exposing, at least in part, his extraordinary and numerous treasures. Besides, he instituted, with his colleague's cooperation and sometimes by himself, the venatorius sport and other kinds of entertainment. The result was that he received, himself, the honors of the expenses which were commonly made, as his colleague Marcus Calpurnius Bibulus did not hide that his situation was like Pollux's: the same way the temple dedicated to the twin brothers [Castor and Pollux], in the forum, showed only Castor's name, also his own munificence and Caesar's were presented as if they were only Caesar's. (SUETONIUS, The 12 Caesars, 2012, p.14).

It was clear, however, that for the optmates as well as for the populares the popular participation was a political instrument and its use as an element of coercion and violence was as important as the presence of the electors. Discoursing about these groups, Sallustius comments: For, to state the truth in few words whatever parties, during that period, disturbed the republic under plausible pretexts, some, as if to defend the rights of the people, others, to make the authority of the senate as great as possible, all, though affecting concern for the public good, contended everyone for his own interest. In such contests there was neither moderation nor limit; each party made a merciless use of its successes. (SALLUSTIUS. Conspiracy of Cantiline XXXVIII. 3.).

For such, both political and social changes from century II BC on, influenced also the political model concerning the plebs' participation. The conceptions of clientela and of an absolutely dependent electoral model and which represented not more than a legitimation of the proposals to be discussed, is not the correct representation when we observe century I BC due to the demographics increase and the use, by the aristocracy, of a popular element. According to North apud Mouritsen, (2007:89): "The popular will of Roman people finds expression in the context, and only in the context, of the oligarchy divisions". The crisis that develops and alternates the dominance of the city among the factions, small groups and individuals, to make room for Augustus Principate leads, for such, the partial mobilization of the plebs, however under the guidance of the dominant class.

Bibliographic References

ALFOLDY, Geza. A História Social de Roma. Editora Presença: Lisboa, 1989 
BRENNAN, T. Corey, apud HOLKESKAMP, Karl-j. Reconstructing the Roman Republic. Princeton university press: New Jersey, 2010

BRUNT, P. A. Social Conflicts in the Roman Republic. Norton \& Company: New York, 1997.

FUNARI, Pedro Paulo. Política e identidade em Roma Republicana. In. FUNARI, Pedro Paulo. \& OLIVEIRA, Maria Aparecida. Política e identidade no mundo antigo. Anablume: São Paulo, 2009

GELZER, Mathias, The Roman Nobility. Barnes \& Noble Inc.: New York, 1969

HOLKESKAMP, Karl-j. Reconstructing the Roman Republic. Princeton university press: New Jersey, 2010.

KONRAD, C. F. From the Gracchi to the first Civil War. In. ROSENSTEIN, Nathan \& MORSTENMARX, Robert. (Org.). The Cambridge companion to the Roman Republic. Blackwell: Oxford, 2006

LINTOTT, Andrew. The Crises of the Republic: Sources and source-problems. In: The Cambridge Ancient History: The last age of the Roman Republic, 146-43 BC.: Cambridge University Press,1992.

MILLAR, Fergus. The crowd in Rome in the Late Republic. The university of Michigan press: Michigan, 2002.

Popular politics at Rome in the late Republic. In: MALKIN,I \& RUBINSOHN,Z.W, Leaders and masses in the Roman world. E.J.Brill: New York, 1995.

MORSTEIN-MARX, Robert. Mass oratory and political Power at the late Roman Republic. Cambridge University Press: New York, 2004.

MOURITSEN, Henrik. Plebs and politics in the late Roman Republic. Cambridge University Press: New York 2007

NIPPEL,Wilfried. Public order in ancient Rome. Cambridge university press: New York,1995

NORTH, John A. The constitution of the Roman Republic. In. ROSENSTEIN, Nathan \& MORSTEN-MARX, Robert. (Org.). The Cambridge companion to the Roman Republic. Blackwell: Oxford, 2006

Politics and aristocracy in the Roman Republic. In. Classical Philology, Vol. 85, No.04. 1990. p. 277.

POBJOY, Marc. Epigraphy and numismatics. . In. ROSENSTEIN, Nathan \& MORSTEN-MARX, Robert. (Org.). The Cambridge companion to the Roman Republic. Blackwell: Oxford, 2006 
SYME, Ronald. The Roman revolution. Oxford University Press: Oxford.2001

TAYLOR, Lily Ross, Party Politics in the age of Caesar. University of California Press: Los Angeles,1949

.Roman voting assemblies: From the Hanibalic war to the dictatorship of Caesar. University of Michigan Press: New York, 1966

\section{Documentary References}

DIONÍSIO DE HALICARNASSO, Roman Antiquities,, Volume I: Books 1-2. Translated by Earnest Cary. Loeb Classical Library 319. Cambridge, MA: Harvard University Press, 1937

QUINTUS TULLIUS CICERO. Comentariolum Petitionis, Trad. Robert Wind. Pennsylvania State University: 1989

SUETONIUS. The 12 Ceasers. Trad. Pietro Nasset. Martin Claret: São Paulo, 2004

GAIUS SALLUSTIUS CRISPUS. The Cantiline Conspiracy. Loeb Classical Library. Trad. J. C. Rolfe. Ed. Willian Heinemann. London: 1921

Jugurthine War, Loeb Classical Library. Trad. J. C. Rolfe. Ed. William Heinemann.

Londres: 1921. 
